\title{
Graft survival of Pinus engelmannii Carr. in relation to two grafting techniques with dormant and sprouting buds
}

\author{
Alberto Pérez-Luna ${ }^{1,2}$, José Ciro Hernández-Díaz ${ }^{3}$, Christian Wehenkel $^{3}$, Sergio Leonel Simental-Rodríguez ${ }^{1}$, \\ Javier Hernández-Velasco ${ }^{1}$, José Ángel Prieto-Ruíz ${ }^{\text {Corresp. } 4}$ \\ 1 Programa Institucional de Doctorado en Ciencias Agropecuarias y Forestales, Universidad Juárez del Estado de Durango, Durango, Durango, Mexico \\ 2 Academia de Física, Centro de Bachillerato Tecnológico Industrial y de Servicios Número 89, Durango, Durango, Mexico \\ 3 Instituto de Silvicultura e Industria de la Madera, Universidad Juárez del Estado de Durango, Durango, Durango, Mexico \\ 4 Facultad de Ciencias Forestales, Universidad Juárez del Estado de Durango, Durango, Durango, Mexico \\ Corresponding Author: José Ángel Prieto-Ruíz \\ Email address: jprieto@ujed.mx
}

Developing methods for successfully grafting forest species will be helpful for establishing asexual seed orchards and increasing the success of forest genetic improvement programs in Mexico. In this study we investigated the effects of two grafting techniques (side veneer and top cleft) and two phenological stages of the scion buds (end of latency and beginning of sprouting), in combination with other seven grafting variables, on the sprouting and survival of 120 intraspecific grafts of Pinus engelmannii Carr. The scions used for grafting were taken from a 5.5-year-old commercial forest plantation. The first grafting was performed on January 18 (buds at the end of dormancy) and the second on February 21 (buds at the beginning of sprouting). The data were examined by analysis of variance and a test of means and were fitted to two survival models (the Weibull's accelerated failure time and the Cox's proportional hazards model) and the respective hazard ratios were calculated. Survival was higher in the top cleft grafts made with buds at the end of latency, with $80 \%$ sprouting and an estimated average survival time of between 164 and 457 days after the end of the six-month evaluation period. Four variables (grafting technique, phenological stage of the scion buds, scion diameter and rootstock height) significantly affected the risk of graft death in both survival models. Use of top cleft grafts with buds at the end of the latency stage, combined with scion diameters smaller than $11.4 \mathrm{~mm}$ and rootstock heights greater than $58.5 \mathrm{~cm}$, was associated with a lower risk of death. 
1 Graft survival of Pinus engelmannii Carr. in relation to two 2 grafting techniques with dormant and sprouting buds

3

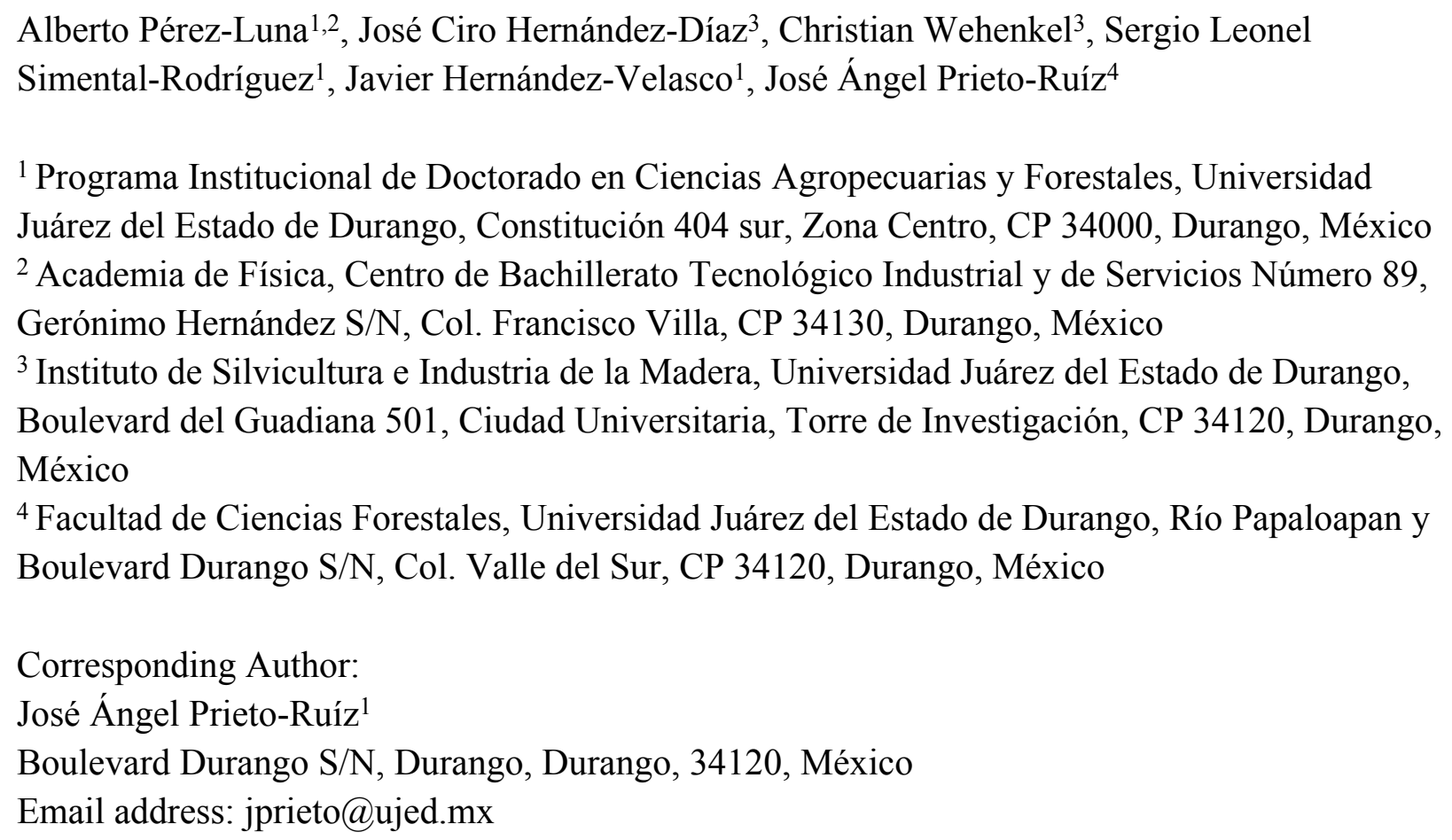

\section{Abstract}

Developing methods for successfully grafting forest species will be helpful for establishing asexual seed orchards and increasing the success of forest genetic improvement programs in Mexico. In this study we investigated the effects of two grafting techniques (side veneer and top cleft) and two phenological stages of the scion buds (end of latency and beginning of sprouting), in combination with other seven grafting variables, on the sprouting and survival of 120 intraspecific grafts of Pinus engelmannii Carr. The scions used for grafting were taken from a 5.5-year-old commercial forest plantation. The first grafting was performed on January 18 (buds at the end of dormancy) and the second on February 21 (buds at the beginning of sprouting). The data were examined by analysis of variance and a test of means and were fitted to two survival models (the Weibull's accelerated failure time and the Cox's proportional hazards model) and the respective hazard ratios were calculated. Survival was higher in the top cleft grafts made with buds at the end of latency, with $80 \%$ sprouting and an estimated average survival time of between 164 and 457 days after the end of the six-month evaluation period. Four variables (grafting technique, phenological stage of the scion buds, scion diameter and rootstock height) significantly affected the risk of graft death in both survival models. Use of top cleft grafts with buds at the end of the latency stage, combined with scion diameters smaller than $11.4 \mathrm{~mm}$ and rootstock heights greater than $58.5 \mathrm{~cm}$, was associated with a lower risk of death. 
40 Keywords Asexual propagation, Apache pine, Top cleft grafting, Side veneer grafting, Grafting 41 survival, Statistical survival analysis models

\section{Introduction}

43 An average area of land of 212,000 hectares was deforested annually in Mexico between 2001

44

45

46

47

48

49

50

51

52

53

54

55

56

57

58

59

60

61

62

63

64

65

66

67

68

69

70

71

72

73

74

75

76

77

78

79 and 2018 (CONAFOR, 2020), mainly due to overexploitation, forest fires, cattle ranching, clandestine logging, adverse weather conditions and a shift in land use from forest to grassland (FAO-CONAFOR, 2009). Between 1970 and 2014 deforestation caused the loss of more than $23,000,000$ ha of tropical forest and more than 13,000,000 ha of temperate forest (SEMARNAT, 2018). These figures place Mexico among the first countries worldwide in terms of loss of forest area.

Mexico also has an annual deficit of $11,619,300 \mathrm{~m}^{3}$ of round and manufactured wood, as well as a deficit of $6,535,500 \mathrm{~m}^{3}$ of cellulosic products (SEMARNAT, 2017). The constant demand for timber products from North America indicates that the consumption in Mexico is three times higher than the production (SEMARNAT, 2017). By contrast, the United States of America annually consumes $20 \%$ more wood than is produced nationally (Fiedler et al., 2001).

Considering forest deterioration, the high demand for wood products and the projected further $33 \%$ increase in demand for timber products by 2030 (Perlis, 2009), seeking ways to increase the supply of wood from Mexican forests is imperative.

Commercial forest plantation programs are particularly important in this respect (Martínez \& Prieto, 2011). However, there are several deficiencies in the production chain for this option, including lack of high quality genetic germplasm, among other factors (Vargas \& López, 2017). In the state of Durango (Mexico), between 0.9 and 1.4 million hectares of forest cover were lost in the period 1986-2012 due to various factors, such as forest fires, land use change, overgrazing and over-exploitation of forests (Novo-Fernández et al., 2018). Fortunately, the state has $1,150,000$ ha of land with a high potential for establishing commercial forest plantations (Martínez \& Prieto, 2011). Pinus engelmannii Carr. is a promising candidate for this purpose, as it is one of the most economically and environmentally important species, mainly due to the high quality of its wood (Prieto et al., 2004; González-Orozco et al., 2018). Establishment of forest plantations in previously non-forested land can contribute to the conservation of natural forest resources (Ramírez \& Simonetti, 2011) and to generating environmental services, such as carbon sequestration (Miehle et al., 2006; Soto-Cervantes et al., 2020), water harvesting, soil retention (Sayer \& Elliott, 2005) and landscape improvement (Sabogal, Besacier \& McGuire, 2015), among others (Martínez \& Prieto, 2011).

The success of commercial forest plantations depends on the use of high-quality genetic material, which can be obtained from asexual seed orchards (Yuan et al., 2016; Stewart et al., 2016; Pérez-Luna et al., 2020a). To establish this type of orchard, superior genotypes must first be multiplied, either by grafting, air layering, cutting or by in vitro propagation (Iglesias, Prieto \& Alarcón, 1996; Bonga, 2016). Grafting is the propagation method most commonly used for cloning superior genotypes of forest species (Stewart et al., 2016). Grafts can be made by taking scions from identified superior trees growing in natural environments and grafting them onto 
80

81

82

83

84

85

86

87

88

89

90

91

92

93

94

95

96

97

98

99

100

101

102

103

104

105

106

107

108

109

110

111

112

113

114

115

116

117

118

119

rootstocks (branches or rhizomes) from other trees, which are typically grown in a nursery, giving rise to new plants (Jayawickrama, Jett \& McKeand, 1991; Muñoz et al., 2013).

Graft success is also influenced by factors such as grafting technique, phenological stage of the scion buds (Jayawickrama, Jett \& McKeand, 1991), genetic, anatomical and taxonomic compatibility between scions and rootstocks (Pina \& Errea, 2005), efficient nutrition (Mutabaruka, Cook \& Buckley, 2015), the grafter's training and skill, and the graft development environment (Muñoz et al., 2013).

Survival equations, such as the Weibull's accelerated failure time model and its hazard function, enable estimation of the probability of success and prediction of the survival time, after the last evaluation in the study period (Zhang, 2016). This model has mainly been used in the field of medicine (Chaou et al., 2017) but has recently been applied in studying the success of grafting tree species (Pérez-Luna et al., 2020b).

Another widely used non-parametric survival model, especially in medical science, is the Cox's proportional hazards model - and the associated hazard ratio - which measures the risk of death of a group of individuals subjected to two or more treatments (Meira-Machado et al., 2013; Gandrud 2015). Pérez-Luna et al. (2019) recently demonstrated the potential use of this model to study the effect of several factors on graft survival and suggested that these modelling techniques are widely applicable in forestry research.

The objectives of the present study were to evaluate the effect of the grafting technique and the phenological stage of the scion buds on the percentage graft survival in P. engelmannii. In addition, the potential effects of another seven variables on graft survival were evaluated. For this purpose, a Weibull's accelerated failure time model and the associated hazard ratio were tested, also the Cox's proportional hazards model was fitted to the data. Given the scarce use of these models in the field of forestry, another important objective of this work was the validation of their usefulness for explaining the effect of diverse factors on the survival of $P$. engelmannii grafts.

\section{Materials \& Methods}

\section{Rootstock production}

The rootstocks were produced in the "General Francisco Villa" forest nursery in Durango, Mexico ( $23^{\circ} 58^{\prime} 20^{\prime \prime}$ North and $104^{\circ} 35^{\prime} 56^{\prime \prime}$ West, at $1,875 \mathrm{~m}$ elevation). During the first year, the rootstocks were grown in polystyrene trays with 77 cavities (each with a capacity of 170 $\mathrm{mL}$ ); the substrate was a mixture of equal parts of peat moss and composted pine bark. In the second year, each rootstock was transplanted into a $3.5 \mathrm{~L}$ black polyethylene bag, which contained equal parts of forest soil and pine bark.

The main physical properties of the substrate were as follows: electrical conductivity, 0.16 mmhos $\mathrm{cm}^{-1} ; \mathrm{pH} 6.04$; organic matter content, $3.8 \%$; and organic carbon content, $2.2 \%$. The total porosity, aeration porosity and the water-holding capacity of the substrate were calculated with the methodology proposed by Landis et al. (1990), yielding values of $82 \%, 44 \%$ and $38 \%$ respectively. Analysis of the chemical properties of the substrate revealed values of $1.02 \%$ for nitrogen-ammonium (N-NH4), 16.73\% for phosphorus (P) and 1.8\% for potassium (K). 
120 At age four years (July 2018), and six months before grafting, the rootstocks were transplanted to

$1215 \mathrm{~L}$ containers (bags), to favour reactivation of the root system. The substrate was forest soil, and 122 to each container we added $50 \mathrm{~g}$ of Multicote ${ }^{\mathrm{TM}}$ 6: 18-6-12 (N-P-K) + micronutrients, which is a 123 slow-release fertilizer manufactured by the Haifa Group ${ }^{\mathrm{TM}}$, with a longevity of 6 months at an 124 average temperature of $21^{\circ} \mathrm{C}$. The rootstocks were watered every three days, with $2 \mathrm{~L}$ of water 125 per plant.

\section{Collection of scions}

127 The scions were taken from trees in a commercial plantation of $P$. engelmannii, in the Ejido 128 Aquiles Serdán, Durango, Mexico (location 23 53' 39" North and 104 33' 44" West and 1,898 129 m elevation). The plantation was five years old when the scions were collected and showed good 130 adaptation and growth. The selected donor trees were of average height $3 \mathrm{~m}$ and diameter $7 \mathrm{~cm}$ at 131 the base of the stem. The scions were collected the day before grafting and placed in layers in 72 132 L plastic boxes; each layer of scions was covered with sawdust wetted with a solution of $3 \mathrm{~g} \mathrm{~L}^{-1}$ 133 of Captán ${ }^{\circledR}$ fungicide, to prevent fungal damage.

\section{Grafting}

135 Grafting was carried out in the nursery of the Institute of Forestry and Wood Industry of the 136 Universidad Juárez del Estado de Durango (ISIMA-UJED), in a greenhouse of dimension $6 \times 8$ $137 \times 3 \mathrm{~m}$ (width $\times$ length $\times$ height $)$, covered with white plastic (caliber 720$)$. To prevent excessive 138 temperatures being reached and to promote adequate relative humidity, two shading meshes 139 (providing 50\% and 70\% cover) were placed over the greenhouse, $30 \mathrm{~cm}$ above the plastic cover. 140 In addition, two air conditioning systems were installed at each end of the greenhouse. The average temperature was maintained at $22{ }^{\circ} \mathrm{C}$ (maximum, $26{ }^{\circ} \mathrm{C}$ and minimum, $7{ }^{\circ} \mathrm{C}$ ) and the

142 relative humidity fluctuated between 72 and $82 \%$.

143 Treatments evaluated

144 The grafting methods evaluated were the side veneer technique described by Muñoz et al. (2013) 145 and Pérez-Luna et al. (2019) and the top cleft technique described by Muñoz et al. (2013). For 146 each technique, two phenological stages of the buds were tested; half of the grafts were made 147 with scion buds at the end of latency (grafted on January 18, 2019) and the other half were made 148 with the scion buds at the beginning of the sprouting stage (grafted on February 21, 2019). In 149 total, four treatments were evaluated, with 120 grafts (60 of side veneer and 60 of top cleft). 150 Thirty grafts of each phenological condition of the buds were made with each grafting technique. 151 For the side veneer graft, a longitudinal cut of $6 \mathrm{~cm}$ was made on one side of the scion and a wedge of approximately one centimetre was formed with a cut at the lower end of the other side

153 (Fig. 1A). A lateral cut was made in the rootstock, of the same length as the cut on the scion, and 154 a one-centimetre slit was left at the end of the cut on the rootstock, into which the scion wedge was inserted and tied (Fig. 1B). For the top cleft graft, two longitudinal $6 \mathrm{~cm}$ cuts were made at the bottom and opposite sides of the scion, forming a wedge shape; the central leader was eliminated from the rootstock, and a central cut (fissure) was made to an approximate depth of $6 \mathrm{~cm}$, into which the scion wedge was inserted (Fig. 1C). The two components of the graft were then tied together (Fig. 1D). 
160 The grafts were tied (both techniques) with transparent rubber tape and sealed with vinyl paint

161

162

163

164

165

166

167

168

169

170

171

172

173

174

175

176

177

178

179

180

181

182

183

184

185

186

187

188

189

190

191

192

193

194

195

196

197

198

199

mixed with $3 \mathrm{~g} \mathrm{~L}^{-1}$ of Captán ${ }^{\circledR}$ fungicide, to prevent pathogens entering the graft union. Finally, a $5 \mathrm{~L}$ transparent plastic bag was placed around the grafted area, into which $1 \mathrm{~L}$ of water was poured to generate a humid microenvironment (Fig. 1E); in addition, each graft was covered with a kraft paper bag, which provided protection from solar radiation (Fig. 1F).

The grafts were watered every three days with plain water. In addition, from the third month of evaluation, Promyl ${ }^{\circledR}$ fungicide was added to the irrigation water $\left(2 \mathrm{~g} \mathrm{~L}^{-1}\right)$ every eight days, to prevent fungal damage. To compensate for possible nutrient deficiency due to the loss of mycorrhiza caused by fungicide application, fertigation was applied during the six-month evaluation period by adding Ultrasol ${ }^{\circledR}$ Triple 19 (N-P-K) $+\mathrm{MgO}+$ micronutrients, a watersoluble fertilizer manufactured by Soquimich commercial, at a dose of $3 \mathrm{~g} \mathrm{~L}^{-1}$ to the water. The solution was applied in a $7 \mathrm{~L}$ manual watering can.

\section{Experimental design and variables evaluated}

The treatments were applied in a $2 \times 2$ factorial experimental design $(2$ grafting techniques $\times 2$ phenological stages of the scion buds). Each experimental unit consisted of 10 grafts, with three repetitions per treatment. Before grafting, seven internal grafting variables of the scion and rootstock were measured (Table 1).

Sprouting and survival of the grafts were evaluated monthly for six months, and the data were examined by the Kolmogorov-Smirnov test to evaluate the normality of the variables evaluated. Analysis of variance (ANOVA) was used to detect potential significant differences between treatments. When significant differences were indicated and the variables were normally distributed, a post hoc Tukey's means test was carried out, with an initial confidence interval of $95 \%(\alpha=0.05)$. The Bonferroni correction was applied to reduce the probability of making a type I error (Garamszegi, 2006; Napierala, 2012); the corrected significance value was $\alpha^{*}=$ 0.0125. In addition, Student's t-tests were used to determine any significant differences in graft survival due to different levels of the independent factors, i.e. side veneer grafts vs top cleft grafts and scions with buds at the end of latency vs scions with buds at the beginning of sprouting. In order to reduce the effect of extreme observations, before performing the analysis of variance and Student's t tests (Burbidge, Magee \& Robb, 1988) the survival value of each treatment was transformed, by calculating the square root of the sine function of the survival quotients.

Finally, the Weibull's accelerated failure time model was fitted to the data to predict the estimated graft survival time after the evaluation period, and the associated hazard ratio was also calculated. Other hazard ratios were estimated using the Cox's proportional hazards model. All statistical analyses were implemented in the "Survival" package in the free R software $(R$ Development Core Team, 2018).

\section{Fitting the Weibull's accelerated failure time model and the hazard ratio}

To fit the accelerated failure time model to the graft survival data, the following independent variables were used: grafting technique, phenological stage of the scion buds and the seven grafting variables (Table 1). To detect the significant variables affecting the estimated survival

Peer] reviewing PDF | (2021:02:57827:3:0:NEW 17 Aug 2021) 
200 time of the grafts, stepwise regression was applied using the "StepReg" package in $\mathrm{R}(R$

201 Development Core Team, 2018). The Weibull's accelerated failure time model is defined as 202 follows:

$$
\operatorname{Ln}(T)=\alpha+\delta x_{i}+\sigma \varepsilon
$$

203

204

205

206

207

208

209

210

211

212

213

214

215

216

217

218

219

220

221

222

223

224

225

226

227

228

229

230

231

232

233

234

235

236

237

where $\operatorname{Ln}(T)$ is the natural logarithm of the mean survival time (T) after the study, i.e. at time $(T)$ at least one death may occur among the grafts that were alive at the end of the evaluation period; $\alpha$ is a scale parameter of the model, $\delta$ is the coefficient of the explanatory variable, $\sigma$ is the shape parameter of the model and $\varepsilon$ is the error of the distribution function (George, Seals \& Aban, 2014; Zhang, 2016). The Weibull's hazard ratio is described as follows:

$$
H R_{W}=\left(e^{-\beta}\right)^{\lambda-1}
$$

where $H R_{W}$ is the Weibull's hazard ratio, which represents the increase or decrease in the risk of death of grafts as a function of the independent variables; $\beta$ is a coefficient that indicates the effect of a given independent variable (from the same $x i$ variables used in Eq. 1). The value of the dependent variable is not used in equation (2), because the Weibull hazard ratio is considered to be "constant for each variable", i.e. there is only one hazard ratio value for each explanatory variable in the model $(I g l, 2018)$. The $\beta$ coefficient is interpreted as follows: if $\beta$ is positive the risk of death decreases as the value of the independent variable decreases, and if $\beta$ is negative, the risk of death decreases as the value of the independent variable increases (Carroll, 2003). Finally, $\lambda$ is a shape parameter of the model. If $\lambda>1$ the hazard ratio increases, and if $\lambda<1$ the hazard ratio decreases (Zhang, 2016). The $\beta$ and $\lambda$ parameters were calculated with flexible parametric regression, which is useful for modelling survival from a time of origin to the instant at which an event occurs (life or death) (Igl 2018; Pérez-Luna et al., 2020b).

The Weibull hazard ratio can take values ranging between 0 and $\infty$ (Ruiz, 2012). A hazard ratio of 0 indicates that the risk of death decreases by $100 \%[(0-1) \times 100)]$. A hazard ratio of $>0$ but $<$ 1 , for example $H R_{W}=0.5$, indicates that the risk of death due to the effect of a variable is reduced by $50 \%[(0.5-1) \times 100)]$ when the level of that particular variable changes. On the other hand, if the hazard ratio is 1.0, the risk of death does not vary due to the effect of changes in some particular variable $[(1-1) * 100)]$; if the hazard ratio takes a value of 2 , the risk of death doubles, i.e. the risk of death increases by $100 \%$ due to the effect of changes in the explanatory variable $[(2-1) \times 100)]$ (Hilsenbeck et al., 1998; Spruance et al., 2004). Interpretation of the hazard ratio is similar for values greater than 2 (Ruiz, 2012). It is important to take into account that the Weibull hazard ratio is calculated individually for each dependent variable in the model (Zhang, 2016).

For fitting these models, dummy variables were used to code the dependent variable (survival) and the independent variables (grafting technique and phenological stage). Therefore, a live graft was coded as 0 and a dead graft as 1 (censor variables). The coding for the grafting technique was 1 for side veneer grafts and 2 for top cleft grafts; the phenological stage was coded as 1 for cuttings with buds at the end of dormancy and 2 for cuttings with buds at the beginning of

Peer) reviewing PDF | (2021:02:57827:3:0:NEW 17 Aug 2021) 
238

239

240

241

242

243

244

245

246

247

248

249

250

251

252

253

254

255

256

257

258

259

260

261

262

263

264

265

266

267

268

269

270

271

272

273

274

275

276

sprouting. For more details on the Weibull's accelerated failure time model and its hazard ratio, see Pérez-Luna et al. (2020b).

\section{Fitting the Cox's proportional hazards model}

The variables shown in Table 1 were used to fit this model, and the most significant variables were selected by stepwise regression. The Cox's proportional hazards model used for calculating hazard ratios is as follows:

$$
H R_{C}=e^{\left(\varphi_{1} x_{i 1}+\ldots+\varphi_{\mathrm{k}} x_{i k}\right)}
$$

where $H R_{C}$ is the Cox's hazard ratio expressed as a function of the independent variables (xi) with which the model is fitted in order to predict the increase or decrease in the risk of death of the individuals under study (grafts). $\varphi$ represents the fit parameters of the model, up to the k-th independent variable. If a given $\varphi$ is positive, the hazard ratio increases when the value of the corresponding $x$ increases (decreasing the probability of survival); if the value of a $\varphi$ is negative, the hazard ratio decreases when the respective $x$ increases (increasing the probability of survival). The range of values and the interpretation of the Cox's hazard ratio are the same as for the Weibull's hazard ratio. The Cox's hazard ratio value is calculated globally, i.e. by including all the independent variables at one time in the $H R_{C}$ equation (Ata \& Sözer, 2007).

Several authors recommend the use of hazard ratios derived from the Weibull's model, as long as the shape parameter of the model $(\lambda)$, which must be calculated before using the hazard ratio (Lee and Wang, 2003; Lawless, 2011), is known; however, its counterpart, the hazard ratio of the Cox's proportional hazards model, does not depend on the evaluation time or predicted survival and therefore has the advantage of being less restrictive than the $H R_{W}(C o x, 1972)$.

To calculate the hazard ratio for graft survival using the Cox's proportional hazards model, dummy variables, including censor variables (dead grafts), were also used, so that the coding for the dependent variables was the same as in the Weibull model. Further details on the use of this model to assess graft survival are given by Pérez-Luna et al. (2019).

\section{Results}

The results of the survival analyses were congruent with the estimated hazard ratios, as can be seen in the results described below.

\section{Survival}

Six months after grafting, the average survival of the grafts made with the top cleft and side veneer techniques were $56.7 \%$ and $18.3 \%$, respectively, with significant differences between them. There were also differences in regard to the phenological stages of the buds, analyzed as individual factors (Table 2 and Fig. 2), yielding 50\% survival in grafts with buds at the end of latency and $25 \%$ survival in the grafts with buds at the beginning of sprouting.

The analysis of variance indicated significant differences (before the Bonferroni correction) due to the effect of these two treatments (Table 2); however, after Bonferroni correction only the grafting technique was statistically significant. Furthermore, the Tukey test revealed that the best interaction was the combination of top cleft grafts with the scion buds at the end of the latency, with $80 \%$ survival, while the treatment yielding lowest survival $(16.7 \%)$ was the side veneer grafts with the scion buds at the beginning of sprouting (Fig. 3). 
277 Fitting the Weibull's accelerated failure time model and the hazard ratio

278 The stepwise regression indicated that survival can be described with only four independent

279 variables, using the Weibull's accelerated failure time model for which the lowest value of the

280 Akaike information criterion (AIC) was achieved (Table 3). The model fit was highly significant, 281 even after Bonferroni correction $(p<0.0001)$, for predicting the mean graft survival time after

282 finishing the six-month evaluation period.

283 In addition, all parameters estimated for the fitting of this four-variable model were significant

284 for the original critical level proposed at the beginning $(p<0.05)$, and only the phenological stage

285 of the buds was not significant after the Bonferroni correction $(p<0.0125)$ (Table 4$)$.

286 Application of the accelerated failure time model (Eq. 1) to the data showed that the estimated

287 time of survival, after finishing the evaluation period, was greater for those grafts produced by

288 the top cleft technique $(x=2)$ and with scions' buds at the end of latency $(x=1)$. In addition, the

289 estimated survival time was greater when the diameter of the scion was less than $11.4 \mathrm{~mm}(x \leq 1)$

290 and the height of the rootstock greater than $58.5 \mathrm{~cm}(x \geq 1)$. The longest estimated average

291 survival time, after the observation period (six months), was 457 days, while the shortest

292 estimated average survival time was 164 days.

293 The estimates depend on the combinations of the values of each independent variable, and these

294 results represent the estimated time during which at least one death could occur among the grafts

295 that were alive at the end of the evaluation period (Zhang, 2016; Pérez-Luna et al., 2020b).

296 The estimated parameters (calculated by regression) for fitting the Weibull hazard function

297 (Zhang, 2016) are shown in Table 5. A negative sign of the $\beta$ coefficient indicates that when the

298 variable "grafting technique" increases by one unit, from $x=1$ (side veneer graft) to $x=2$ (top

299 cleft graft), the risk of death of at least one graft will be reduced by $76 \%\left[\left(H R_{W}-1\right) \times 100=(0.24-\right.$

300 1) $\times 100=-76 \%$ ]; that is, the risk of death decreases by $76 \%$ when grafting with the top cleft

301 technique. Interpretation of the negative value of the $\beta$ estimator of the variable "rootstock

302 height" is the same as the case described above; therefore, for rootstocks of height greater than

$30358.5 \mathrm{~cm}$, the risk of death of the grafts is reduced by $4 \%\left[\left(H R_{W}-1\right) \times 100=(0.96-1) \times 100=-\right.$

$3044 \%$ ]. On the other hand, the positive signs of $\beta$ for the variables "phenological stage of buds" and

305 "diameter of scion" indicate that by increasing the respective variable by one unit, the risk of

306 death of the grafts will increase according to the value obtained for each hazard ratio; thus, in the

307 case of the "phenological stage of buds" for $x=2$ (grafts with buds at the beginning of

308 sprouting), the risk of death increased by $64 \%\left[\left(H R_{W^{-}}-1\right) \times 100=(1.64-1) \times 100=64 \%\right]$ when the

309 phenological stage is $x=1$ (grafts with buds of scions at the end of dormancy). Finally, for

310 scions of diameter greater than $13.38 \mathrm{~mm}$, the risk of death of the grafts increased by $25 \%$

$311\left[\left(H R_{W^{-}}-1\right) \times 100=(1.25-1) \times 100=25 \%\right]$.

312 Fitting the Cox's proportional hazards model

313 Using stepwise regression, the variables that best explained the hazard ratio in graft survival

314 were also selected by fitting the Cox proportional hazards model and it was confirmed that the

315 grafting technique, the phenological stage of the buds, the rootstock height and the scion

316 diameter were the outstanding variables for the best fit (Table 6). 
317 The variables that best explained the hazard ratio of the Cox's proportional hazards model were 318 the same variables selected for fitting the Weibull's accelerated failure time model, and although 319 Tables 3 and 6 are similar, note that the value of the Akaike's information criterion was lower in 320 Table $6(\mathrm{AIC}=609.6)$ than that shown in Table $3(\mathrm{AIC}=904.8)$. Therefore, the Cox's

321 proportional hazards model performed better than Weibull's model for predicting the survival 322 probability. The estimators calculated for fitting the Cox's model are shown in Table 7.

323 The hazard ratio values (Table 8) were calculated using equation (3). It was estimated that the 324 lowest value of the hazard ratio of grafts death (0.18) would be obtained for the top cleft grafts

325

326

327

328

329

330

331

332

333

334

335

336

337

338

339

340

341

342

343

344

345

346

347

348

349

350

351

352

353

354

355

356 with the scion buds at the end of the dormancy period, using rootstocks taller than $58.5 \mathrm{~cm}$ and scions with diameter smaller than $11.4 \mathrm{~mm}$; this value implies that the risk of death would decrease by $82 \%\left[\left(H R_{C}-1\right) \times 100=(0.18-1) \times 100=-82 \%\right]$ when grafts are produced with this combination of variables, relative to the hazard ratio obtained for other combinations. On the other hand, the highest estimated hazard ratio corresponded to the side veneer grafts using scions with buds at the beginning of sprouting, for rootstocks shorter than $58.5 \mathrm{~cm}$ and scions with diameter greater than $11.4 \mathrm{~mm}$, taking a value of 2.0 , which indicates that the risk of death under this combination increases by $100 \%\left[\left(H R_{C^{-}}-1\right) \times 100 ;(2-1) \times 100=100 \%\right]$, relative to the other combinations.

\section{Discussion}

In this study, a higher survival of top cleft grafts was observed (56.7\%) than in side veneer grafts (18.3\%); the two types of grafts were maintained under climate-controlled conditions within the greenhouse. Temperature control during coniferous grafting is important to increase the survival probability, as observed by Blada \& Panea (2011), who found that callus formation in side veneer grafts of Picea pungens Engelm var. glauca Regel was favoured by temperatures between 20 and $25^{\circ} \mathrm{C}$.

In a recent study in Durango, Mexico, Pérez Luna et al. (2019) performed side veneer grafting with 5 to 7 -year-old rootstocks of Pinus engelmannii, under greenhouse conditions without automatic climate control, and reported survival of only $22.5 \%$ six months after grafting, with no significant differences between grafting using scions with buds at the end of dormancy or at the beginning of sprouting. These low survival results were attributed by the authors to the high temperatures registered in the greenhouse during the months of March to May (maximum recorded, $42.6^{\circ} \mathrm{C}$ ), and to the low relative humidity in the same months (on average, $38 \%$ ). However, in the present study, the survival obtained in the side veneer grafts, were similar to obtained for Pérez-Luna et al. (2019), indicating that climate control appears to be ineffective in this regard.

On the other hand, the higher survival of the top cleft grafts than of the side veneer grafts achieved in the present study may be related to the more favourable (controlled) environment (maximum temperature of $26^{\circ} \mathrm{C}$ and minimum relative humidity of $72 \%$ ) inside the greenhouse. However, low temperatures also usually strong affect the survival of coniferous grafts, as observed by Cuevas (2014), who reported $100 \%$ mortality in top cleft and side veneer grafts of Pinus leiophylla Schiede ex Schltdl. et Cham for a minimum temperature of $-5.8^{\circ} \mathrm{C}$. 
357 In side veneer grafts of Pinus greggii Engelm var. australis Donahue \& López in Veracruz,

358

359

360

361

362

363

364

365

366

367

368

369

370

371

372

373

374

375

376

377

378

379

380

381

382

383

384

385

386

387

388

389

390

391

392

393

394

395

396

survival was greater than $60 \%$ after three months, which was partially attributed to the fact that both the seedlings with which the rootstocks were produced and the grafted scions were obtained from the same geographic location (Alba-Landa et al., 2017). In the present study, the scions and rootstocks were of different origin, which may contribute to explaining the low percentage of successful grafts with this technique. In this respect, some studies did not observe any effect of the origin on the success of grafting; e.g. Aparicio et al. (2009) reported that the provenance of the scions did not influence the survival of terminal fissure grafts of Austrocedrus chilensis (D. Don) Pic Serm \& Bizzarri; however, Villaseñor \& Carrera (1980) reported that the provenance of the scions had a significant effect on the success of the top cleft and side veneer grafting of Pinus patula Schl. et Cham.

The genetic compatibility between the scion and the rootstock is also a determining factor in grafting success (Lott et al., 2003; Hibbert-Frey et al., 2001); in this regard, it is important to consider the results of recent studies (Wehenkel et al., 2020; Simental-Rodriguez et al., 2021), which indicate large genetic differences and even hybridizations between close populations of the genus Pinus in northern Mexico.

On the other hand, Wendling, Stuepp \& Zuffellato-Ribas (2016) found that grafting of Araucaria angustifolia (Bertol.) Kuntze was effective with the chip budding technique (which is similar to the side veneer grafting regarding the cut made in the rootstock), reporting almost $40 \%$ survival at 130 days after grafting.

Mencuccini et al. (2007) recommend using rootstocks younger than two years for grafting Pinus species. Dorman (1976) pointed out that the sprouting of side veneer grafts in Pinus species was significantly lower when rootstocks older than three years were used. In the present study, the rootstocks were older than four years and the survival of side veneer grafts was low (18.3\%) despite the fact that the rootstocks used in both grafting techniques were of the same age; however, the survival of top cleft grafts $(56.7 \%)$ can be considered acceptable. In another study, Zhang \& Tang (2005) reported 50\% survival in top cleft grafting of Pinus ponderosa Douglas ex C. Lawson with two-year-old rootstocks. In the top cleft graft of Pinus elliottii Engelm., a survival rate of $30 \%$ was reported for grafting performed with two- to three-year-old rootstocks (Mergen, 1955).

Other authors have also achieved good survival when grafting conifers with the top cleft technique. For example, Almqvist $(2013 a ; 2013 b)$ reported survival rates of 75.0 and $84.7 \%$ in two Pinus sylvestris L. top cleft grafting experiments. In Abies fraseri (Pursh) Poir grafts, Hibbert-Frey et al. (2011) reported $86 \%$ survival with the same technique. Similarly, Singh (1992) reported good success when grafting Pinus gerardiana Wall, using the top cleft technique, with $70 \%$ survival.

Villaseñor \& Carrera (1980) reported survival of $63.0 \%$ in top cleft grafts of Pinus patula in Mexico, using scions with dormant buds. Likewise, Świerczyński et al. (2020) achieved survival greater than $80 \%$ for side veneer grafts on Pinus mugo Turra, established in winter (using scions with dormant buds). Survival greater than $60.0 \%$ was reported for top cleft grafts of Araucaria

Peer) reviewing PDF | (2021:02:57827:3:0:NEW 17 Aug 2021) 
397

398

399

400

401

402

403

404

405

406

407

408

409

410

411

412

413

414

415

416

417

418

419

420

421

422

423

424

425

426

427

428

429

430

431

432

433

434

435

436

angustifolia, in Brazil, using scions with dormant buds (Gaspar et al., 2017). On the other hand, when grafting A. angustifolia, Zanette, Oliveira \& Biasi (2011) reported only $20 \%$ and $0 \%$ survival in grafts with buds at the beginning of sprouting (spring) and during full sprouting (summer), respectively. These results are consistent with those obtained in the present study and, although different species of the order Pinales were used, they must share certain characteristics in terms of their phenological functioning (Bodnar et al., 2015).

To analyze graft survival, Pérez-Luna et al. (2020b) fitted the Weibull's accelerated failure time model to data on side veneer grafts of Pinus engelmannii, estimating an average survival time of 154 days after the end of the six-month evaluation period. The higher values of potential survival time (up to 457 days) observed in the present study can be attributed to the automated temperature and environmental humidity controls in the greenhouse where the grafting was conducted in the present study. By contrast, only two shading meshes (providing 70 and 50\% light retention) were placed above the greenhouse in the previous study, to reduce the temperature inside.

The negative values of the estimators of the coefficients of the explanatory variables in Table 7 appeared in the same variables that had already been detected when calculating the Weibull hazard function (for "grafting technique" and "height of rootstock") (Table 5). Interpretation of the algebraic signs of the estimators is similar in both tables and is based on the interpretation of Table 5, which refers to the risk of death of the grafts (Cox, 1972). Therefore, the negative values of the estimators shown in Table 7 also indicate that the risk of death of the grafts decreases when the value of these variables increases, i.e. when $x_{i}>1$; i.e. when using the top cleft grafting technique and when the height of the rootstock is greater than the mean value observed (58.5 $\mathrm{cm}$ ), the risk of death decreases and therefore, the probability of survival increases. On the other hand, the positive values of the variables "phenological stage of buds" and "diameter of scion" indicate that the risk of death increases when $x i>1$ (grafts with buds at the beginning of sprouting and scions with diameters greater than the observed mean value, i.e. $11.4 \mathrm{~mm}$ ). The effects of the other seven grafting variables considered in the present study (Table 1) were also evaluated in the aforementioned study (Pérez-Luna et al., 2020b), and it was found that these variables did not significantly affect the risk of graft death. The significant effects observed in the present study contrast with these previous findings, which can be attributed to the fact that on this occasion the climatic conditions inside the greenhouse were controlled, thus reducing the variation caused by factors not evaluated. The survival of the grafts can therefore be more directly attributed to their response to the treatments and to the grafting variables evaluated. In a grafting experiment with Araucaria angustifolia, Wendling, Stuepp \& Zuffellato-Ribas (2016) obtained survival greater than $20 \%$ after 130 days of evaluation for rootstocks between 80 and $100 \mathrm{~cm}$ in height; our findings indicate that the survival of $P$. engelmannii grafts is improved by using rootstocks taller than $55.8 \mathrm{~cm}$.

Using scions with diameter larger than the rootstock diameter can cause localized graft incompatibility. This effect was visualized by Sweet \& Thulin (1973), who reported this type of incompatibility in grafts of Pinus radiata D. Don, as the cambium did not coincide between the 
437 grafted organs. On the other hand, Pérez-Luna et al. (2020) observed that when using short 438 rootstocks of $P$. engelmannii (less than $30 \mathrm{~cm}$ ), the graft was also short (less than $15 \mathrm{~cm}$ height in 439 average), hampering establishment of a protective microenvironment and subsequent 440 management of the grafts.

441 Pérez-Luna et al. (2019) also used the Cox's proportional hazards model and the associated 442 hazard ratio to evaluate the effect of the phenological stage of the scion buds (end of latency and 443 beginning of sprouting), observing that this factor did not have a significant influence on the risk 444 of graft mortality. The difference in the hazard ratio due to the effect of the phenological stage of 445 the scion buds in the present study relative to the aforementioned research can mainly be 446 attributed to the differences in management of the greenhouse conditions, as in the previous 447 study the climate control was not used.

448 Conclusions

449 Two survival models used in medical studies proved useful tools for evaluating the success of $P$.

450

451

452

453

454

455

456

457

458

459

460

461

462

463

464

465

466

467

468

469

470

471

472

473

474

475

476

engelmannii grafts. Thus, the Weibull's accelerated failure time model and the Cox's

proportional hazards model and their respective hazard ratios were validated for use in predicting the survival rate (risk of death) as a function of the factors considered, such as the grafting technique, the phenological stage of scion buds and some other grafting variables inherent to the scions and rootstocks. Although the Cox's proportional hazards model provided a better fit to the data, the use of the Weibull's accelerated failure time model is also recommended, as it enabled reliable prediction of the estimated graft survival time after the end of the evaluation period. The best grafting technique for asexual propagation of $P$. engelmannii proved to be the top cleft method, and the best phenological condition for the scion buds was at the end of the latency period. Grafting was more successful with scions of diameter smaller than $11.4 \mathrm{~mm}$. In addition, in order to reduce the risk of death of top cleft and side veneer grafts of $P$. engelmannii, the use of rootstocks taller than $58.5 \mathrm{~cm}$ is recommended. The results of the present study can serve as a guide for decision-making for grafting in the studied species.

\section{Acknowledgements}

The authors are grateful to Andrea Losoya Simental for help with English language editing. We also thank Rosa Elvira Madrid Aispuro, Silvia Salcido Ruiz and Manuel González Romero for assistance with grafting activities.

\section{References}

Alba-Landa J, Mendizábal-Hernández LDC, Ramírez-García E, Márquez R J, Cruz-Jiménez H, Rodríguez-Juárez MC. 2017. Injertos de fenotipos selectos de Pinus greggii Engelm. de una prueba genética en Villa Aldama, Veracruz, México. Foresta Veracruzana 19:57-61.

Almqvist C. 2013a. Survival and strobili production in top grafted scions from young Pinus sylvestris seedlings. Scandinavian Journal of Forest Research 28:533-539 DOI: 10.1080/02827581.2013.803598.

Almqvist C. 2013b. Interstock effects on top graft vitality and strobili production after top grafting in Pinus sylvestris. Canadian journal of forest research 43:584-588 DOI: 10.1139/cjfr-2012-0507.

Peer) reviewing PDF | (2021:02:57827:3:0:NEW 17 Aug 2021) 
477

478

479

480

481

482

483

484

485

486

487

488

489

490

491

492

493

494

495

496

497

498

499

500

501

502

503

504

505

506

507

508

509

510

511

512

513

514

515

Aparicio A, Pastorino M, Martínez-Meier A, Gallo L. 2009. Propagación vegetativa del ciprés de la cordillera, una especie vulnerable del bosque subántartico de Sudamérica. Bosque (Valdivia) 30: 18-26 DOI: 10.4067/S0717-92002009000100004

Ata N, Sözer MT. 2007. Cox regression models with nonproportional hazards applied to lung cancer survival data. Hacettepe Journal of Mathematics and Statistics 36:157-167.

Blada I, Panea T. 2011. Improvement of grafting procedures for the ornamental species: I. Picea pungens Engelm. var. glauca Regel. Annals of Forests Research 54:185-196.

Bodnar J, Ruiz DP, Artabe AE, Morel EM, Ganuza D. 2015 Voltziales y Pinales (= Coniferales) de la Formación Cortaderita (Triásico Medio), Argentina, y su implicancia en la reconstrucción de las coníferas triásicas. Revista Brasileira de Paleontologia 18:141-160 DOI: $10.4072 /$ rbp.2015.1.10.

Bonga JM. 2016. Conifer clonal propagation in tree improvement programs. In: Park YS, Moon HK, eds. Vegetative propagation offorest trees. Seoul: National Institute of Forest Science (NiFos), 3-31.

Burbidge JB, Magee L, Robb AL. 1988. Alternative transformation to handle extreme values of the dependent variable. Journal of the American Statistical Association83:123-127 DOI: $10.1080 / 01621459.1988 .10478575$.

Carroll KJ. 2003. On the use and utility of the Weibull model in the analysis of survival data. Control Clinical Trials 24:682-701 DOI: 10.1016/s0197-2456(03)00072-2.

Chaou CH, Chen HH, Chang SH, Tang P, Pan SL, Yen AMF, Chiu TF. 2017. Predicting length of stay among patients discharged from the emergency department - using an accelerated failure time model. PLoS ONE 12: e0165756 DOI: 10.1371/journal.pone.0165756.

CONAFOR (Comisión Nacional Forestal). 2020. El sector forestal mexicano en cifras 2020. Available at https://drive.google.com/drive/folders/luqxvg_BNvQOfqSxRKKUW1oBNdqMOY8QC (accessed 04 May 2021).

Cox DR. 1972. Regression models and life-tables. Journal of the Royal Statistical Society: Series $B$ (Methodological 34:187-202 DOI: 10.1111/j.2517-6161.1972.tb00899.x.

Cuevas Cruz JC. 2014. Propagación vegetativa de Pinus leiophylla Schiede ex Schltdl. et Cham. M.S. thesis, Colegio de Postgraduados.

Dorman KW. 1976. The genetic and breeding of southern pines. United States: Department of Agriculture Forest Service.

Garamszegi LZ. 2006. Comparing effect sizes across variables: generalization without the need for Bonferroni correction. Behavioral Ecology 17:682-687 DOI: 10.1093/beheco/ark005.

Gaspar RGB, Wendling I, Stuepp CA, Angelo AC. 2017. Rootstock age and growth habit influence top grafting in Araucaria angustifolia. CERNE 23:465-471 DOI: 10.1590/01047760201723042447.

George B, Seals S, Aban I. 2014. Survival analysis and regression models. Journal of nuclear cardiology 21:686-694 DOI: 10.1007/s12350-014-9908-2. 
516 González-Orozco MM, Prieto-Ruíz JÁ, Aldrete A, Hernández-Díaz JC, Chávez-Simental JA, 517 Rodríguez-Laguna R. 2018. Nursery production of Pinus engelmannii Carr. with substrates 518 based on fresh sawdust. Forests 9:678 DOI: 10.3390/f9110678.

519 FAO-CONAFOR. 2009. Revisión del Programa Estratégico Forestal 2025 (PEF 2025) y del

520

521

522

523

524

525

526

527

528

529

530

531

532

533

534

535

536

537

538

539

540

541

542

543

544

545

546

547

548

549

550

551

552

553

Programa Nacional Forestal 2001-2006 (PNF 2001-2006), en el marco del proyecto $\mathrm{UTF} / \mathrm{MEX} / 072$. Available at

http://www.conafor.gob.mx:8080/documentos/docs/4/4402Revision\%20del\%20PEF\%2020 25\%20y\%20PRONAFOR\%202001-2006.pdf (accessed 05 February 2021).

Fiedler CE, Arno SF, Keegan CE, Blatner KA. 2001. Overcoming America's wood deficit: an overlooked option. AIBS Bulletin 51:53-58 DOI: 10.1641/0006-

3568(2001)051[0053:OASWDA]2.0.CO;2.

Hibbert-Frey H, Frampton J, Blazich FA, Hundley D, Hinesley E. 2011. Grafting fraser fir (Abies fraseri): effect of scion origin (crown position and branch order). HortScience 46:91-94 DOI: 10.21273/HORTSCI.46.1.91.

Hilsenbeck SG, Ravdin MPM, de Moor CA, Chamness GC, Osborne CK, Clark MC. 1998. Time-dependence of hazard ratios for prognostic factors in primary breast cancer. Breast Breast cancer research and treatment 52: 227-237 DOI: 10.1023/A:1006133418245.

Igl W. 2018. Calculation of hazard ratios of parametric survival model in R-A tutorial [Draft]. Available at http://wilmarigl.de/wpcontent/uploads/2018/01/tutorial_hr_parsurvmodels.pdf(accessed 05 February 2021). Iglesias GL, Prieto RJÁ, Alarcón BM 1996. La propagación vegetativa de plantas forestales. Revista Ciencia Forestal en México 21:15-41.

Jayawickrama KJS, Jett JB, McKeand SE. Rootstock effects in grafted conifers: A review. 1991. New Forests 5:157-173 DOI: 10.1007/BF00029306.

Landis TD, Jacobs DF, Wilkinson KM, Luna T. 1990. Growing media. In: Landis TD, Tinus RW, Tinus RW, McDonald SE, Barnett JP (eds.). The container tree nursery Manual, vol. 2. Agric. Handbk. 674. Department of Agriculture, Forest Service. Washington, DC. 4185.

Lawless JF. 2011. Statistical models and methods for lifetime data. New Jersey: John Wiley \& Sons.

Lee ET, Wang J. 2003. Statistical methods for survival data analysis. New Jersey: John Wiley \& Sons.

Lott LH, Lott LM, Stine M, Kubisiak TL, Nelson CD. 2003. Top grafting longleaf $\times$ slash pine F1 hybrids on mature longleaf and slash pine interstocks. In: Tree Improvement and Genetics $27^{\text {th }}$ Sothern Forest Tree Improvement Conference, Oklahoma. 96-101.

Martínez SM, Prieto RJÁ. 2011. Determinación de áreas potenciales para el establecimiento de plantaciones comerciales forestales en la región norte de México. México: Instituto Nacional de Investigaciones Forestales Agrícolas y Pecuarias (INIFAP).

PeerJ reviewing PDF | (2021:02:57827:3:0:NEW 17 Aug 2021) 
554

555

556

557

558

559

560

561

562

563

564

565

566

567

568

569

570

571

572

573

574

575

576

577

578

579

580

581

582

583

584

585

586

587

588

589

590

591

592

593

Mencuccini M, Martínez-Villalta J, Hamid HA, Korakaki E, Vanderklein D. 2007. Evidence for age-and size-mediated controls of tree growth from grafting studies. Tree Physiology 27:463-473 DOI: 10.1093/treephys/27.3.463.

Mergen F. 1955. Grafting slash pine in the field and in the greenhouse. Journal of Forestry 53:836-842 DOI: $10.1093 /$ jof/53.11.836

Miehle P, Livesley SJ, Feikema PM, Li C, Arndt SK. 2006. Assessing productivity and carbon sequestration capacity of Eucalyptus globulus plantations using the process model ForestDNDC: calibration and validation. Ecological Modelling 192: 83-94 DOI: 10.1016/j.ecolmodel.2005.07.021.

Muñoz FHJ, Coria AVM, García SJJ, Velasco BE, Martínez MG. 2012. Evaluación de una plantación de Pinus greggii Engelm. con dos espaciamientos. Revista mexicana de ciencias forestales 3:57-70.

Muñoz FHJ, Prieto RJÁ, Flores GA, Pineda OT, Morales GE. 2013. Técnicas de injertado "enchapado lateral" y "fisura terminal" en Pinus pseudostrobus Lindl. México: Instituto Nacional de Investigaciones Forestales Agrícolas y Pecuarias (INIFAP).

Mutabaruka C, Cook HF, Buckley GP. 2015. Effects of drought and nutrient deficiency on grafts originating from sound and shaken sweet chestnut trees (Castanea sativa Mill.). iForestBiogeosciences and Forestry 9:109-114 DOI: 10.3832/ifor1572-008.

Napierala MA. 2012. What is the Bonferroni correction? AAOS Now 6:40.

Novo-Fernández A, Franks S, Wehenkel C, López-Serrano PM, Molinier M, López-Sánchez CA. 2018. Landsat time series analysis for temperate forests cover change detection in the Sierra Madre Occidental, Durango México. International Journal of Applied Earth Observation and Geoinformation 73:230-244 DOI: 10.1016/j.jag.2018.06.015.

Perlis A. 2009. State of the world's forests 2009. Rome: Food and Agriculture Organization (FAO).

Pérez-Luna A, Prieto-Ruíz JÁ, López-Upton J, Carrillo-Parra A, Wehenkel C, Chávez-Simental JA, Hernández-Díaz JC. 2019. Some factors involved in the success of side veneer grafting of Pinus engelmannii Carr. Forests 10:112 DOI: 10.3390/f10020112

Pérez-Luna A, Whenkel C, Prieto-Ruíz JÁ, López-Upton J, Solís-González S, Chávez-Simental JA, Hernández-Díaz JC. 2020a. Grafting in conifers. A review. Pakistan Journal of Botany 52(4):1369-1378 DOI: 10.30848/PJB2020-4(10)

Pérez-Luna A, Wehenkel C, Prieto-Ruíz JÁ, López-Upton J, Hernández-Díaz JC. 2020 b. Survival of side grafts with scions from pure species Pinus engelmannii Carr. and the $P$. engelmannii $\times$ P. arizonica Engelm. var. arizonica hybrid. PeerJ 8:e8468 DOI: 10.7717/peerj. 8468

Prieto RJÁ, Cornejo OEH, Domínguez CPA, Návar CJDJ, Marmolejo MJG, Jiménez PJ. 2004. Estrés hídrico de Pinus engelmannii Carr., producido en vivero. Forests Systems 13:443451.

R Development Core Team. 2018. R: A language and environmental for statistical computing. Vienna: The $\mathrm{R}$ foundation for statistical computing. 
594 Ramírez PA, Simonetti JA. 2011. Conservation opportunities in commercial plantations: the case

595

596

597

598

599

600

601

602

603

604

605

606

607

608

609

610

611

612

613

614

615

616

617

618

619

620

621

622

623

624

625

626

627

628

629

630

631

632 of mammals. Journal for Nature Conservation 19: 351-355 DOI: 10.1016/j.jnc.2011.06.003.

Ruíz JS. 2012. Control global del riesgo cardiometabólico: La disfunción endotelial como diana preferencial. Madrid: Ediciones Díaz de Santos.

Sabogal C, Besacier C, McGuire D. 2015. Restauración de bosques y paisajes: conceptos, enfoques y desafíos que plantea su ejecución. Unasylva 66:3-10.

Sayer J, Elliot C. 2005. The role of commercial plantations in forest landscape restoration. In: Mansourian S, Vallauri D eds. Forest restoration landscapes: beyond planting trees. New York: Springer Science \& Business Media, 379-383.

SEMARNAT (Secretaría de Medio Ambiente y Recursos Naturales). 2017. Anuario estadístico de la producción forestal 2017. Available at http://dsiappsdev.semarnat.gob.mx/datos/portal/publicaciones/2020/2017.pdf(accessed 05 February 2021).

SEMARNAT (Secretaría de Medio Ambiente y Recursos Naturales). 2018. Informe de la situación del medio ambiente en México 2018. Available at https://apps 1.semarnat.gob.mx:8443/dgeia/informe18/index.html (accessed 05 February 2021).

Simental-Rodríguez SL, Pérez-Luna A, Hernández-Díaz JC, Jaramillo-Correa JP, LópezSánchez CA, Flores-Rentería L, Carrillo-Parra A, Wehenkel C. 2021. Modelling shifts and contraction of seed zones in two Mexican pine species by using molecular markers. Forests 12:570 DOI: 10.3390/f12050570

Singh NB. 1992. Propagation, selection and establishment of clonal seed orchard of chigoza pine (Pinus gerardiana Wall.). Indian Forester 118:901-908.

Soto-Cervantes JA, Carrillo-Parra A, Rodríguez-Laguna R, Corral-Rivas JJ, Pompa-García M, Domínguez-Calleros PA. 2020. Survival, growth and carbon content in a forest plantation established after a clear-cutting in Durango, México. PeerJ 8:e9506 DOI: 10.7717/peerj.9506

Spruance SL, Reid JE, Grace M, Samore M. 2004. Hazard ratio in clinical trials. Antimicrobial agents and chemotherapy 48:2787-2792 DOI: 10.1128/AAC.48.8.2787-2792.2004.

Stewart JF, Will R, Crane BS, Nelson D. 2016. Occurrence of shortleaf x loblolly pine hybrids in shortleaf pine orchards: implications for ecosystem restoration. Forest Science 63:225-231 DOI: 10.5849/forsci.15-167.

Sweet GB, Thulin IJ. 1973. Graft incompatibility in radiata pine in New Zealand Forest Service. New Zealand Journal of Forestry Science 3:82-90.

Świerczyński S, Kolasiński M, Stachowiak A, Rybus-Zając M. 2020. Influence of rootstocks and the time of grafting two cultivars of mountain pine (Pinus mugo Turra) and estimation of chloroplast pigments level in the needles. Acta Scientiarum Polonorum-Hortorum Cultus 19:75-85 DOI: 10.24326/asphc.2020.2.8. 
633 Vargas HJJ, López UJ. 2017. Propuesta de mejora genética en apoyo a los programas de 634 plantaciones forestales comerciales en el sureste de México. Ciudad de México: Comisión 635 Nacional Forestal (CONAFOR).

636 Villaseñor RR, Carrera GMVS. 1980. Tres ensayos de injerto en Pinus patula Schl. et Cham.

637 Ciencia Forestal 5:22-35.

638 Wehenkel C, Mariscal-Lucero SdR, González-Elizondo MS, Aguirre-Galindo VA, Fladung M, 639 López-Sánchez CA. 2020. Tall Pinus luzmariae tres with genes from P. herrerae. PeerJ $640 \quad 8: e 8648$ DOI: $10.7717 /$ peerj. 8648

641 Wendling I, Stuepp CA Zuffellato-Ribas KC. 2016. Araucaria angustifolia grafting: techniques, 642 environments and origin of propagation material. Bosque 37:285-293 DOI:

$643 \quad 10.4067 / \mathrm{S} 0717-92002016000200007$.

644 Yuan H, Niu S, Zhou X, Du Q, Li Y, Li W. 2016. Evaluation of seed production in a first645 generation seed orchard of Chinese pine (Pinus tabuliformis). Journal of forestry research 646 27:1003-1008 DOI: 10.1007/s11676-016-0238-x.

647 Zanette F, Oliveira LDS, Biasi LA. 2011. Grafting of Araucaria angustifolia (Bertol.) Kuntze

648 through the four seasons of the year. Revista Brasileira de Fruticultura 33:1364-1370 DOI:

$649 \quad 10.1590 / \mathrm{S} 0100-29452011000400040$.

650 Zhang CG, Tang DR. 2005. The propagation technique of heteroplastic grafting of Pinus 651 ponderosa [J]. Journal of Northwest Forestry University 2:026.

652 Zhang Z. 2016. Parametric regression model for survival data: Weibull regression model as an 653 example. Annals of Translational Medicine 4:484 DOI: 10.21037/atm.2016.08.45. 


\section{Table $\mathbf{1}$ (on next page)}

Values of graft variables measured in scions, buds and rootstocks of Pinus engelmannii Carr. 
Table 1. Values of graft variables measured in scions, buds and rootstocks of Pinus engelmannii Carr.

\begin{tabular}{lllll}
\hline Graft Variable & $\begin{array}{l}\text { Mini } \\
\text { mum }\end{array}$ & $\begin{array}{l}\text { Mean } \pm \\
\text { standard } \\
\text { deviation }\end{array}$ & Maximum & $\begin{array}{l}\text { Coefficient } \\
\text { of variation }\end{array}$ \\
\hline Length of scion $(\mathrm{cm})$ & 8.5 & $15.1 \pm 3.7$ & 32.0 & 0.24 \\
Diameter of scion (mm) & 7.0 & $11.4 \pm 2.6$ & 18.8 & 0.22 \\
Length of bud (cm) & 0.5 & $2.8 \pm 1.1$ & 5.5 & 0.39 \\
Height of rootstock (cm) & 61.0 & $88.2 \pm 14.2$ & 129.0 & 0.16 \\
Diameter of rootstock at root crown (mm) & 13.3 & $33.4 \pm 5.8$ & 46.7 & 0.17 \\
Height of graft (cm) & 9.0 & $58.5 \pm 26.8$ & 112.0 & 0.45 \\
Diameter of rootstock at graft height $(\mathrm{mm})$ & 7.0 & $18.1 \pm 6.1$ & 32.7 & 0.33 \\
\hline
\end{tabular}


Table 2 (on next page)

Results of the analysis of variance of graft survival.

*, Significance after Bonferroni correction $(\alpha=0.0125)$. 
Table 2. Results of the analysis of variance of graft survival.

\begin{tabular}{|c|c|c|c|c|}
\hline Factor & Degrees of freedom & $\begin{array}{l}\text { Square } \\
\text { mean }\end{array}$ & F value & $\mathbf{p}<\mathbf{F}$ \\
\hline Grafting technique & 1 & 0.44 & 23.00 & $0.001 *$ \\
\hline Phenological stage of the buds & 1 & 0.19 & 9.78 & 0.014 \\
\hline $\begin{array}{l}\text { Interaction of grafting technique } \mathrm{x} \\
\text { phenological stage of the buds }\end{array}$ & 1 & 0.14 & 7.35 & 0.026 \\
\hline
\end{tabular}

1 Note: *, Significance after Bonferroni correction $(\alpha=0.0125)$. 


\section{Table 3 (on next page)}

Selection of the most significant variables by stepwise regression, for fitting the Weibull accelerated failure time model.

AIC, Akaike information criterion; GT, Grafting technique; PSB, Phenological stage of the buds; HR, Height of rootstock; DRRC, Diameter of rootstock at root crown; LS, Length of scion; DS, Diameter of scion; HG, height of graft; DRGH, diameter of rootstock at graft height; $L B$, length of bud. 
Table 3. Selection of the most significant variables by stepwise regression, for fitting the Weibull accelerated failure time model.

\begin{tabular}{lll}
\hline Variables & Number of variables & AIC \\
\hline GT, PSB, HR, DRRC, LS, DS, HG, DRGH, LB & 9 & 910.3 \\
GT, PSB, HR, DRRC, LS, DS, HG, DRGH & 8 & 908.3 \\
GT, PSB, HR, DRRC, LS, DS, HG & 7 & 907.0 \\
GT, PSB, HR, DRRC, LS, DS, & 6 & 906.2 \\
GT, PSB, HR, DRRC, DS & 5 & 905.4 \\
GT, PSB, HR, DS & 4 & 904.8 \\
\hline
\end{tabular}

Note: AIC, Akaike information criterion; GT, Grafting technique; PSB, Phenological stage of the buds; HR, Height of rootstock; DRRC, Diameter of rootstock at root crown; LS, Length of scion; DS, Diameter of scion; HG, height of graft; DRGH, diameter of rootstock at graft height; LB, length of bud. 


\section{Table 4 (on next page)}

Estimated parameters for fitting the Weibull accelerated failure time model, to estimate the survival time of the grafts after the evaluation period.

$*$, *indicates significance after Bonferroni correction $(\alpha=0.0125)$. 
Table 4. Estimated parameters for fitting the Weibull accelerated failure time model, to estimate the survival time of the grafts after the evaluation period.

\begin{tabular}{llll}
\hline Parameter & Estimator & $|\mathbf{z}|$ & $\boldsymbol{p}<|\mathbf{z}|$ \\
\hline Intercept $(\alpha)$ & 4.63375 & 11.11 & $<0.0001^{*}$ \\
Coefficient for "grafting technique" $\left(\delta_{1}\right)$ & 0.66768 & 5.32 & $<0.0001^{*}$ \\
Coefficient for "phenological stage of buds" $\left(\delta_{2}\right)$ & -0.23356 & -2.03 & 0.0425 \\
Coefficient for "diameter of scion" $\left(\delta_{3}\right)$ & -0.10703 & -4.36 & $<0.0001^{*}$ \\
Coefficient for "height of rootstock" $\left(\delta_{4}\right)$ & 0.01440 & 3.11 & $0.0018^{*}$ \\
Model scale $(\sigma)$ & 0.46900 & -7.87 & $<0.0001^{*}$ \\
\hline
\end{tabular}

1 Note: *, indicates significance after Bonferroni correction $(\alpha=0.0125)$. 


\section{Table 5 (on next page)}

Estimated parameters and results of the calculation of the Weibull hazard function, in relation to the risk of death of the grafts.

$H R_{w}$, Weibull hazard ratio; na, there is no hazard ratio value for the shape parameter; *, indicates significance after Bonferroni correction $(\alpha=0.0125)$. 
Table 5. Estimated parameters and results of the calculation of the Weibull hazard function, in relation to the risk of death of the grafts.

\begin{tabular}{llll}
\hline Parameter & Estimator & $\begin{array}{l}\boldsymbol{H} \boldsymbol{R}_{W} \\
\text { value }\end{array}$ & $\boldsymbol{p}<|\mathbf{z}|$ \\
\hline Shape $(\lambda)$ & $5.11 \times 10^{-05}$ & na & $<0.0001^{*}$ \\
Coefficient of "grafting technique" $\left(\beta_{1}\right)$ & -1.42 & 0.24 & $<0.0001^{*}$ \\
Coefficient of "phenological stage of buds" $\left(\beta_{2}\right)$ & $4.98 \times 10^{-01}$ & 1.64 & 0.0425 \\
Coefficient of "diameter of scion" $\left(\beta_{3}\right)$ & $2.28 \times 10^{-02}$ & 1.25 & $<0.0001^{*}$ \\
Coefficient of "height of rootstock" $\left(\beta_{4}\right)$ & $-3.06 \times 10^{-03}$ & 0.96 & $0.0018^{*}$ \\
\hline
\end{tabular}

Note: $H R_{w}$, Weibull hazard ratio; na, there is no hazard ratio value for the shape parameter; *, indicates significance after Bonferroni correction $(\alpha=0.0125)$. 


\section{Table 6(on next page)}

Selection of variables by stepwise regression to adjust the Cox proportional hazards model.

AIC, Akaike information criterion; GT, Grafting technique; PSB, Phenological stage of the buds; HR, Height of rootstock; DRRC, Diameter of rootstock at root crown; LS, Length of scion; DS, Diameter of scion; HG, height of graft; DRGH, diameter of rootstock at graft height; $L B$, length of bud. 
Table 6. Selection of variables by stepwise regression to adjust the Cox proportional hazards model.

\begin{tabular}{lll}
\hline Variables & Number of variables & AIC \\
\hline GT, PSB, HR, DRRC, LS, DS, HG, DRGH, LB & 9 & 615.4 \\
GT, PSB, HR, DRRC, LS, DS, HG, DRGH & 8 & 613.4 \\
GT, PSB, HR, DRRC, LS, DS, HG & 7 & 612.1 \\
GT, PSB, HR, DRRC, LS, DS, & 6 & 611.2 \\
GT, PSB, HR, DRRC, DS & 5 & 610.3 \\
GT, PSB, HR, DS & 4 & 609.6
\end{tabular}

1 Note: AIC, Akaike information criterion; GT, Grafting technique; PSB, Phenological stage of 2 the buds; HR, Height of rootstock; DRRC, Diameter of rootstock at root crown; LS, Length of

3 scion; DS, Diameter of scion; HG, height of graft; DRGH, diameter of rootstock at graft height; 4 LB, length of bud. 


\section{Table 7 (on next page)}

Parameters estimated in fitting the Cox proportional hazards model to calculate hazard ratios in relation to graft survival.

*, indicates significance after Bonferroni correction $(\alpha=0.0125)$. 
Table 7. Parameters estimated in fitting the Cox proportional hazards model to calculate hazard ratios in relation to graft survival.

\begin{tabular}{llll}
\hline Parameter & Estimator & $|\mathbf{z}|$ & $\boldsymbol{p}<|\mathbf{z}|$ \\
\hline Coefficient of "grafting technique" $\left(\varphi_{1}\right)$ & -1.37692 & -5.32 & $<0.0001^{*}$ \\
Coefficient of "phenological stage of buds" $\left(\varphi_{2}\right)$ & 0.54683 & 2.24 & $0.0024^{*}$ \\
Coefficient of "diameter of scion" $\left(\varphi_{3}\right)$ & 0.21635 & 4.12 & $<0.0001^{*}$ \\
Coefficient of "height of rootstock" $\left(\varphi_{4}\right)$ & -0.02964 & -3.03 & $0.0024^{*}$ \\
\hline
\end{tabular}

1 Note: *, indicates significance after Bonferroni correction $(\alpha=0.0125)$. 


\section{Table 8(on next page)}

Estimated values for the Cox hazard ratio in relation to graft survival.

The maximum and minimum values of the Cox hazard ratio are indicated in bold. 
Table 8. Estimated values for the Cox hazard ratio in relation to graft survival.

\begin{tabular}{|c|c|c|c|c|c|c|}
\hline \multicolumn{6}{|c|}{ Combination of variables } & \multirow[b]{2}{*}{$\begin{array}{c}\text { Cox } \\
\text { hazard } \\
\text { ratio }\end{array}$} \\
\hline $\begin{array}{l}\text { Graft } \\
\text { technique }\end{array}$ & $\begin{array}{l}\text { Phenological } \\
\text { stage of } \\
\text { buds }\end{array}$ & $\begin{array}{l}\text { Rootstock } \\
\text { height } \\
\text { greater } \\
\text { than } 55.8 \\
\text { cm }\end{array}$ & $\begin{array}{l}\text { Rootstock } \\
\text { height } \\
\text { less than } \\
55.8 \mathrm{~cm}\end{array}$ & $\begin{array}{l}\text { Scion } \\
\text { diameter } \\
\text { greater } \\
\text { than } 11.4 \\
\text { mm }\end{array}$ & $\begin{array}{l}\text { Scion } \\
\text { diameter } \\
\text { less than } \\
11.4 \mathrm{~mm}\end{array}$ & \\
\hline \multirow{8}{*}{$\begin{array}{l}\text { Side } \\
\text { veneer }\end{array}$} & \multirow{4}{*}{$\begin{array}{l}\text { End of } \\
\text { latency }\end{array}$} & & $\mathrm{X}$ & & $\mathrm{X}$ & 0.75 \\
\hline & & $\mathrm{X}$ & \multirow{3}{*}{$X$} & & $\mathrm{X}$ & 0.71 \\
\hline & & & & $X$ & & 1.15 \\
\hline & & $X$ & & $X$ & & 1.09 \\
\hline & \multirow{4}{*}{$\begin{array}{l}\text { Start of } \\
\text { sprouting }\end{array}$} & & $\mathrm{X}$ & & $\mathrm{X}$ & 1.29 \\
\hline & & $X$ & & & $X$ & 1.22 \\
\hline & & & $X$ & $X$ & & 2.00 \\
\hline & & $\mathrm{X}$ & & $\mathrm{X}$ & & 1.88 \\
\hline \multirow{8}{*}{ Top cleft } & \multirow{4}{*}{$\begin{array}{l}\text { End of } \\
\text { latency }\end{array}$} & & $\mathrm{X}$ & & $\mathrm{X}$ & 0.19 \\
\hline & & $\mathrm{X}$ & & & $X$ & 0.18 \\
\hline & & & $X$ & $X$ & & 0.29 \\
\hline & & $X$ & & $X$ & & 0.27 \\
\hline & \multirow{4}{*}{$\begin{array}{l}\text { Start of } \\
\text { sprouting }\end{array}$} & & $\mathrm{X}$ & & $\mathrm{X}$ & 0.33 \\
\hline & & $X$ & \multirow{3}{*}{$X$} & & $X$ & 0.31 \\
\hline & & & & $\mathrm{X}$ & & 0.50 \\
\hline & & $\mathrm{X}$ & & $\mathrm{X}$ & & 0.47 \\
\hline
\end{tabular}

Note: The maximum and minimum values of the Cox hazard ratio are indicated in bold. 
Figure 1

Grafting techniques and graft protection.

(A) Preparation of the scion used for a side veneer graft; (B) A tied side veneer graft; (C) Preparation of rootstock for a top cleft graft; (D) A tied top cleft graft; (E) A plastic bag being placed over the grafted area containing water to generate the wet microclimate; (F) Protection of the grafted area with a kraft paper bag, to protect the area from direct solar radiation. Photo credit: Alberto Pérez-Luna. 


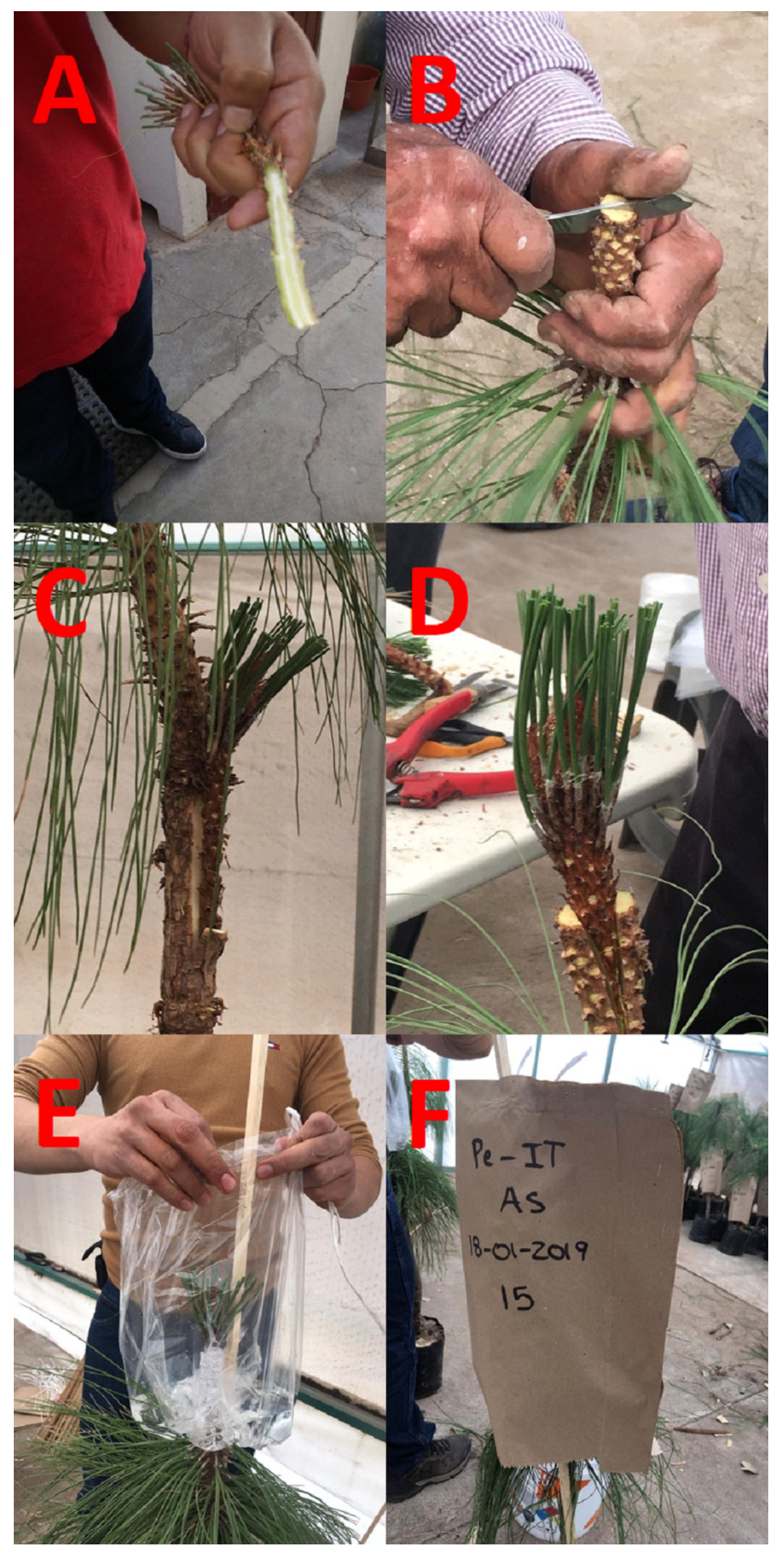

Peer) reviewing PDF | (2021:02:57827:3:0:NEW 17 Aug 2021) 
Figure 2

Graft survival at the end of the six-month evaluation period.

(A) Grafting technique; (B) Phenological stage of the buds. Statistical results based on

Student's t tests. Different letters indicate significant differences between treatments ( $\alpha=$ 0.05), before Bonferroni correction. The whiskers represent the standard error of each treatment.

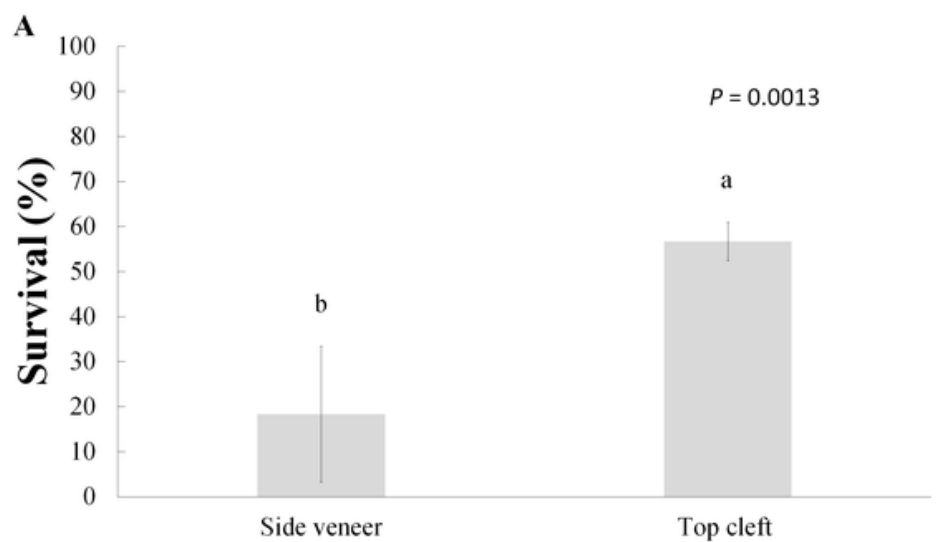

Grafting technique

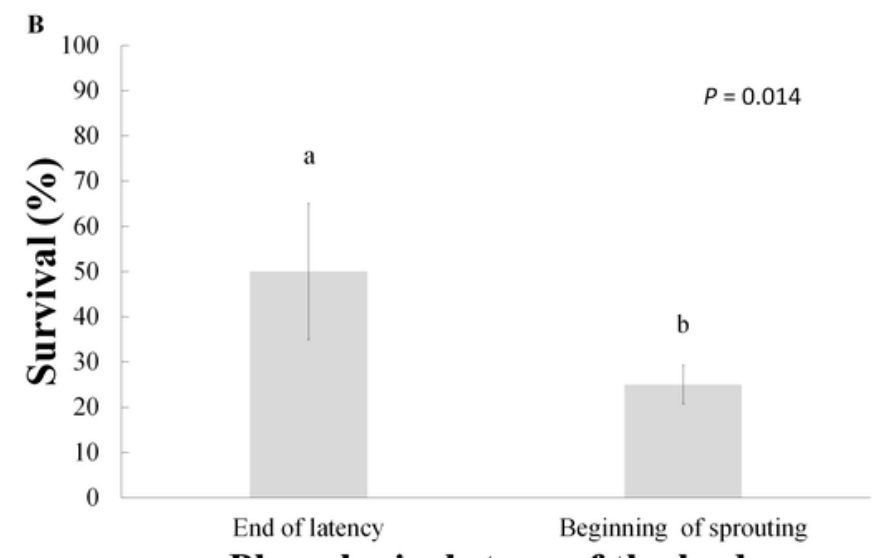

Phenological stage of the buds 
Figure 3

Survival of Pinus engelmannii grafts by treatment, at age six months.

Different letters indicate significant differences between treatments $(\alpha=0.05)$, before

Bonferroni correction. The whiskers represent the standard error of each treatment.

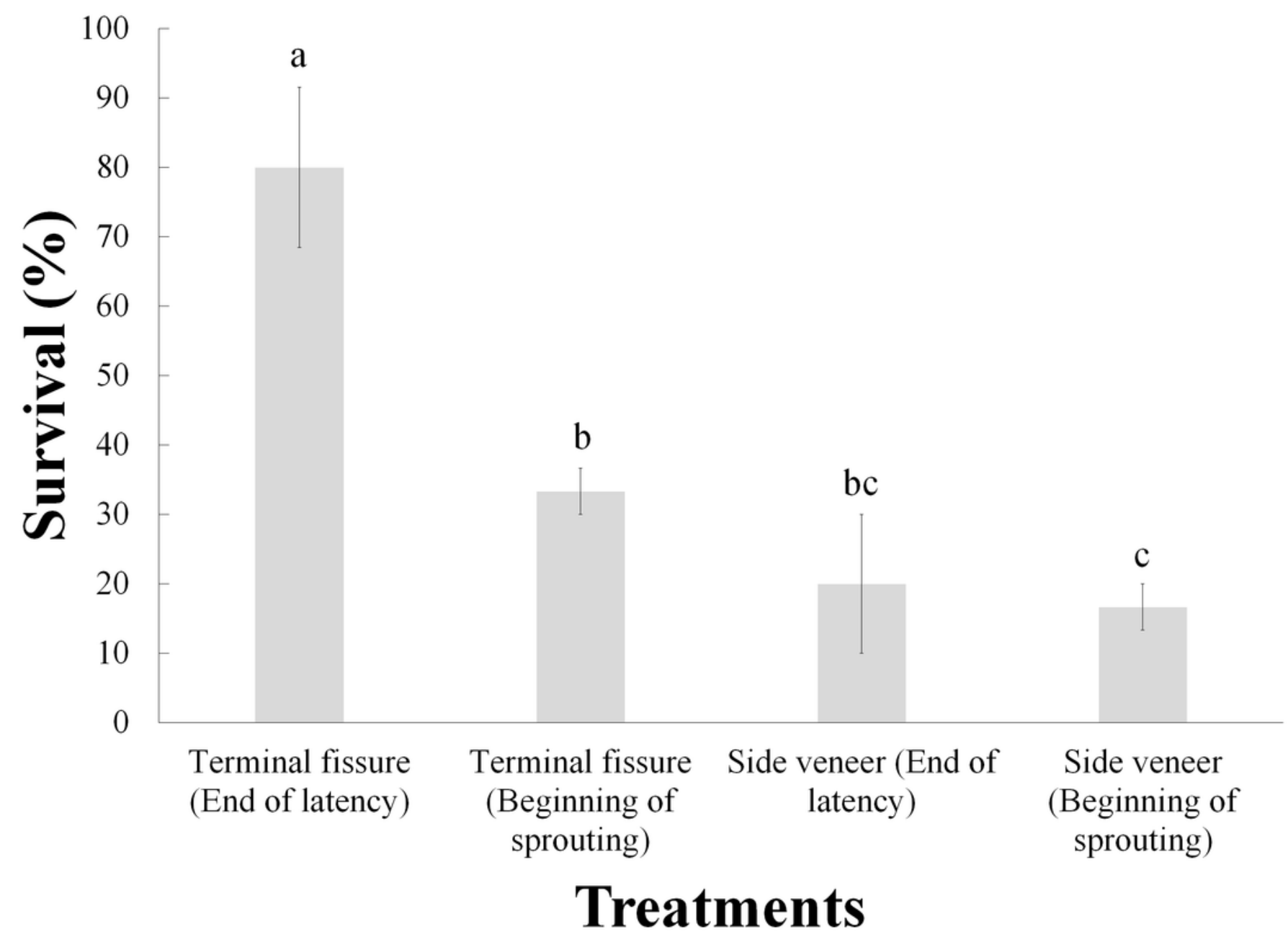

